\title{
Core Psychodynamic Models of Depression and Their Therapeutic Implications
}

\author{
In-Soo Lee \\ In-Soo Lee MD's Psychiatric and Psychoanalytic Clinic, Seoul, Korea
}

\section{우울의 주요 정신역동 모델과 치료적 개입}

\author{
이 인 수 \\ 이인수 정신건강의학과/정신분석클리닉
}

Background: Understanding core psychodynamic models of depression in the transference is a central process of psychodynamic psychotherapy for depressed patients. Aim: This paper reviews updated psychodynamic models of depression such as 1) narcissistic vulnerability and shame, 2) managing conflicted anger and anger directed toward the self, 3) excessive guilt, 4) idealization and devaluation, 5) defenses employed in coping with painful affects, 6) anaclitic or dependent depression, 7) introjective or self-critical depression. This paper also shows clinical implications of these models and important therapeutic tasks for facilitating therapeutic alliance and the ego observational capacities.

Psychoanalysis 2018;29(2):19-26

KEY WORDS: Depression · Mourning · Psychodynamic model · Psychodynamic psychotherapy · Psychoanalytic psychotherapy.

Received: February 26, 2018 Revised: March 18, 2018 Accepted: March 19, 2018

Address for correspondence: In-Soo Lee, MD

In-Soo Lee MD's Psychiatric and Psychoanalytic Clinic, 8 Apgujeong-ro 73-gil, Gangnam-gu, Seoul 06010, Korea

Tel: +82-2-517-7573, Fax: +82-2-517-7574, E-mail: psychoanalysis.lee@gmail.com

\section{서 론}

Freud(1917)가 논문 Mourning and Melancholia를 통해 우울과 애도의 정신분석적 모델을 처음 제시한 이후 현재에 이르기까지 우울에 대한 다양한 형태의 정신역동 모델과 장 기/단기 역동정신치료가 개발되었다. 특히 20세기 후반, 신 경과학과 정신약물학의 발전, 장기간의 정신분석적 정신치 료에 대한 현실적 제한점, 자기애적 병리를 가진 환자군 및 경계선 수준의 환자군에 대한 진단 확대와 치료 기법의 변 형 등은 임상 현장에서 특정한 우울 환자에게 어떠한 치료 적 개입과 기법이 적절할지, 치료 기간의 산정, 정신역동적 치 료의 성격구조 변화 가능성에 대한 복잡한 논의를 일으켰다. 이러한 맥락에서 Malan(1963), Mann(1973), Sifneos(1979), Davanloo(1980), Strupp과 Binder(1984), Pollack과 Horner (1985), 그리고 de Jonghe 등(1994)은 치료 시작 전 6개월 이

This is an Open Access article distributed under the terms of the Creative Commons Attribution Non-Commercial License (http://creativecommons.org/licenses/by-nc/4.0) which permits unrestricted non-commercial use, distribution, and reproduction in any medium, provided the original work is properly cited.
내의 기간 동안 치료 횟수를 미리 정하는 보다 구조화된 Short Term Psychodynamic Psychotherapy(STPP)를 제시 하였다. 비록 전통적인 정신분석적 치료 틀과 기법에서 변형 을 시도하였지만, 이들은 모두 Id psychology, Ego psychology, Object relations theory, Attachment theory, Self psychology 등의 주요 정신분석 이론에 뿌리를 두고 있었으며, 여전히 증상 아래에 있는 개인의 성격구조가 우울증과 같은 증상의 발생과 지속에 매우 중요한 역할을 하고 있다는 점 을 고려하고 있다. 이들의 치료 방향도 우울 증상 감소를 위 한 노력과 통찰을 통한 성격의 변화를 촉진하는 노력 두 가지 방향을 모두 포함하려 하였다. 첫 번째 방향은 대인관계적 측 면(interpersonal relationships)에서 우울 증상을 유발하는 반 복되는 문제적 대인관계 패턴(core relational themes)을 이해 하도록 돕고 구체적인 치료적 개입을 시도하는 것으로 다른 지지 치료나 인지행동치료와 크게 다르지 않다. 두 번째는 비록 시간의 제약이 있고 부분적이지만, 개인의 심리 내적 측면에서 증상을 만드는 무의식적 정신 과정(감정, 방어기 제, 환상)을 더욱 의식화하도록 돕고 개인의 취약성을 줄이 고, 오래 지속되는 회복력을 촉진하여 성격 변화를 돕는 치 
료 개입이다. 이들 대부분이 지지적 기법과 탐색적 기법을 모두 이용하여, 우울 증상 개선이나 통찰을 통한 성격 변화 를 도모하였다. Luborksy(1984)의 분류를 인용하자면 지지적 기법에서 치료관계는 보다 대인관계적으로 형성되고, 공고 하고 지지적인 치료 동맹이 주요 치료 인자이다. 이를 통해 결핍된 심리 내적 구조를 성장시켜가는 것을 목적으로 한다. 반면, 탐색적 접근은 치료 관계 안에서 환자의 심리 내적으로 일어나는 전이 경험을 중점으로 다룬다. 해석을 주요 기법으 로 사용하며, 통찰이 주요 치료 인자이며, 성격의 재구조화를 목적으로 한다.

우울에 대한 역동정신치료의 치료 효과를 연구한 Driessen 등(2010)은 총 1,365 명의 우울증 환자에 대한 23 개의 임상연 구를 검토하여 meta-analysis를 시행하였다. 평균 치료 기간 은 14 18주(대략 16 20 sessions)였으며, 치료 후 시점에서 단기간 역동정신치료를 받은 환자군은 대조군에 비하여 유 의미하게 효과적이었고, 치료 전후 우울 증상 감소의 정도도 유의미하게 컸으며, 이러한 치료 효과는 1년 후 추적연구에 서도 계속 유지되고 있었다. 이 분석에서 흥미로운 점은 지 지적 기법과 통찰적 접근 모두가 동일한 효과를 보였다는 것이다.

본 논문에서는 우울의 중심적인 정신역동적 모델에 대한 최신지견과 그에 맞는 통찰 지향적 치료 기법을 소개하고자 한다. 이를 위해 다음 네 가지 소주제를 차례로 제시할 것이다. 1) 우울과 애도에 관한 정신분석 이론의 역사적 발전, 2) 우울 의 주요 정신역동 모델, 3) 누가 통찰 지향적 정신치료에 적합 한 우울 환자인가?, 4) 우울의 정신역동적 치료: 단계별 과제.

\section{고 찰}

\section{우울과 애도에 관한 정신분석 이론의 역사적 발전}

Kernberg(2010)는 우울과 애도에 대한 주요 이론의 역사 적 발전을 아래와 같이 요약하였다.

\section{Freud}

우울(depression)은 슬픔과 절망, 깊은 낙담과 의기소침이 경험되면서 자존감의 저하가 동반되는 상태를 말한다. 하지 만, 임상에서는 신경증적 우울(depression)과 정상적이고 적 절한 수준의 슬픔(sadness) 혹은 애도(mourning)가 혼용되어 사용되곤 한다. Freud(1917)는 Mourning and melancholia 라는 획기적인 논문에서 이 두 가지 현상을 명확히 구분하여 설명했다. 우울과 애도는 대상 상실이라는 동일한 상황에 의 해 발생하지만, 두 가지는 분명히 다른 독특한 임상 현상이라 는 것이다. 즉, 애도는 정상적인 현상이지만, 우울은 병적인
현상이다. 특히, 우울에서는 매우 고통스러운 자존감 상실이 일어나는 것이 특징이라고 보았다.

정상적인 애도 과정에서는 대상을 상실했다는 현실에 대 한 적절한 인식이 있으며, 대상과의 object tie가 점차 포기되 고, 대상과의 관계를 내면화하는 과정을 거친다. 이를 위해 서 상당한 시간과 정서적 노력이 필요하다. 반면, 우울에서 개인은 잃어버린 대상과의 관계를 포기할 수 없으며, 잃어버 린 대상에 대한 자기애적 동일시(narcissistic identification) 라는 퇴행적 상태가 지속된다고 했다. 이런 상태에 대한 원 인은 대상에 대한 양가적인 감정 때문이다. 개인이 대상에 대해서 사랑뿐만 아니라 강렬한 미움의 감정을 가지고 있고, 그 대상을 잃게 되었을 때 대상을 향한 강렬한 분노와 죄책 감을 경험하게 된다. 이때 분노는 잃어버린 대상을 향하지 못하고, 대상과 동일시된 자신을 공격하며, 그 결과 자존감 의 손상이 일어난다. 또한 Freud(1923)는 상실된 대상은 동 일시를 통해서 대체되며, 자아와 초자아의 발달로 이어진다 고 했다. 이후 불안 이론에서 대상 상실이 일어나려 할 때 불 안이 발생하며, 실제로 대상을 잃었을 때 고통이 발생한다고 설명했다(Freud 1926).

\section{Jacobson}

Jacobson(1971)은 Freud와 유사하게 우울과 애도를 설명 하고 있다. 즉, 정상적인 애도는 실제의 상실이나 상실 환상 의 결과 발생하며, 자신을 향한 공격성 문제는 관여되지 않 는다고 보았다. 반면, 우울은 대상을 상실했을 때 자신을 향 한 공격성이 특징이며, 대상에 대한 공격성은 드러나기도 하 고 나타나지 않기도 하다고 보았다. 또한 우울은 자기애적 갈등이 현저할 때 나타나는 경향이 있다는 점을 추가했다.

\section{Klein}

Klein(1940)은 Freud의 견해와 달리, 개인이 대상을 잃게 될 때는 '항상' 양가감정의 갈등이 일어난다고 보았고, 애도 과정의 고통은 양가감정과 관련된 갈등에서 온다고 하였다. 개인이 외부 대상을 상실했을 때 좋은 내적 대상 (good internal object)도 파괴될 것처럼 몹시 두렵고, 죄책감과 처벌에 대한 환상이 재활성화되는데(depressive position), 사랑하는 대상을 잃는 고통을 줄이기 위해서 애도자(mourner)는 내면 적으로 이상화된 대상(idealized internal object)을 갖고자 한다고 주장했다. 이와 동시에 같은 대상을 향한 미움의 감 정과 공격적 감정이 일어나며, 자신의 공격성이 좋은 내적 대상을 파괴할지도 모른다는 불안도 경험한다. Klein(1940) 은 성공적인 애도의 과정에 대해서 다음과 같이 기술하였다. "정상적인 애도란 고통스럽지만 천천히 현실을 인정하고, 내 
면 세계를 다시 세우고, 외부 세계와 다시 연결되는 것이다. 반면, 병적인 애도는 퇴행 상태의 편집증적 불안이 지속되거나 조증 상태가 지나치게 오래 지속되는 것과 관련되어 있다."

\section{Bowlby}

Bowlby(1961)는 어린아이들도 애도의 과정을 거친다고 하며, 생애 초기 대상 상실의 경험은 성인기 정신병리로 이어 진다고 하였다. 그는 애도의 세 단계를 다음과 같이 기술하였 다. 첫 단계는 사랑하는 대상과의 분리에 대한 실망, 불안, 슬 픔을 느끼는 단계이며, 그 대상을 다시 회복하고자 하는 저항 과 분노의 단계이다. 두 번째 단계는 인격의 와해, 고통, 절망 의 단계이며, 더 이상 잃어버린 대상에 대해 집중하려 하지 않고, 잃어버린 관계를 되찾기 위한 노력 또한 중단하게 된 다. 세 번째 단계는 애도의 종결 단계인데, 잃어버린 대상에 대한 이미지를 재구성하고, 새로운 대상과의 관계를 재계함 으로써 애도가 종결된다고 하였다. Bowlby(1961)는 Freud와 달리 잃어버린 대상을 향한 분노는 공통된 반응으로 보았다. Klein과 달리 죄책감과 처벌에 대한 두려움은 정상 애도의 요소들이 아니라고 주장하면서, 병적 애도는 일반적인 애도 의 강도가 심하게 나타나는 것이며, 첫 번째 애도 단계 이후 로 진행을 하지 못하는 것이라고 정의 내렸다.

\section{Kernberg}

Kernberg(2010)는 정상적인 애도의 과정은 잃어버린 대상 과의 내적 대상관계를 회복하고, 더욱 강하게 하며, 자아 이 상과 초자아의 발달을 가져오며, 그 결과 사랑하는 능력을 더 깊게 한다고 하였다. 더불어 우리는 사랑하는 대상을 잃 어버리기 전에는 그 대상의 가치와 의미를 충분히 알지 못하 기 때문에 대상을 잃고 나서야 상실되어 버린 기회에 대한 후 회나 죄책감을 느낄 수 있다. 하지만 이것은 대상을 향한 공 격성 때문이 아니라고 설명하면서, 사랑하는 대상에 대한 기 억은 이별 이후에도 영구히 강렬하게 남고, 그 대상에 대한 생각이 떠오를 때 눈물과 슬픔으로 경험된다고 하였다.

\section{우울의 주요 역동 모델(Core psychodynamic models of depression)}

초기 우울의 정신분석적 모델은 '분노가 자기를 향하는 것' 이었다(anger turning against the self). Abraham(1911, 1924), Freud(1917), Rado(1928) 등은 자기애적 취약성(narcissistic vulnerability), 발달적 손상(developmental trauma), 실망(disappointment), 상실(loss)이 유발한 anger를 자신에 게로 돌릴 때 우울증이 발생한다고 보았다.

이후 구조 이론, 대상관계 이론, 자기심리학, 애착 이론의
발전과 더불어 우울의 정신분석적 모델은 보다 정교하게 발 전하게 된다. 그 결과 여러 정신분석가들은 '자존감 조절의 문제와 공격성의 문제(problems with self-esteem regulation and aggression)'라는 성격구조의 특성이 우울을 유발한다는 큰 틀의 합의에 이르게 된다(Bibring 1953; Jacobson 1954, 1971, 1975; Stone 1986; Sandler와 Joffe 1965; Brenner 1975, 1979; Kohut 1971; Fonagy와 Target 1997).

통찰 지향적 정신역동치료는 전이 관계 안에서 개인이 가 진 주요 정신역동 모델들을 이해해 가는 방향으로 치료가 전개된다. 본 논문에서는 Busch(2016)가 제시한 다섯 가지 주요 정신역동 모델과 Blatt(2004)이 제시한 두 가지 정신역 동 모델을 고찰하고, 각 역동에 따른 적절한 치료 개입과 기 법을 간략하게 소개하고자 한다.

\section{자기애적 취약성(Narcissistic vulnerability)}

우울의 근간에는 뿌리 깊은 자기애적 취약성이 있다. 이 취 약성이 자극될 때 분노하게 되며, 우울하게 된다. 자기애적 취약성의 원인은 어린 시절 경험된(실제이거나 지각된 것이 거나) 상실, 거절, 버림받음의 경험에서 개인은 자신에 대한 매우 부정적인 이미지와 부적절감을 내면화하는 것에서 비 롯한다. 그 결과 마음과 신체에 심각한 결함이 있을 것이며, 모든 사람들이 자신을 거부하고 떠나가게 될 것이라는 무의 식적 환상을 갖게 된다. 이로 인해 타인의 무시, 비난, 거절에 대한 극도의 예민성을 가지게 되고, 곧 자존감의 상실, 무가 치감, 우울감과 여러 형태의 신체 증상이 발생하며, 자신에 게 자기애적 상처를 준 대상에 대한 강렬한 격노(narcissistic rage)를 갖는다.

자기애적 취약성에 대한 정신역동적 치료 과정은 취약성 의 원인을 함께 이해해 가는 과정이다. 개인이 경험한 어린 시절의 고통스러운 헤어짐, 부모로부터의 거절 경험, 남과의 차이를 인식함으로써 발생하는 자존감 취약성, 생명을 위협 하는 어린 시절의 질병의 영향과 같은 원인을 찾아간다. 또한 자기 자신과 타인에 대한 왜곡된 지각을 인식하도록 돕는다. 자기애적 취약성을 경험할 때 발생하여 증상을 유발하는 환 상들, 방어기제, 행동 패턴을 인식하도록 돕는다.

\section{분노에 대한 갈등(Conflicted anger)}

우울한 사람은 자존감에 상처를 주는 대상, 자신의 욕구나 소망에 대해서 반응하지 않는 대상, 자신이 갖지 못한 것을 가지고 있는 대상에게 분노감을 경험하게 된다. 이때 분노에 대해서 억압할 것인지 표출할 것인지에 대한 극심한 내적 갈등을 겪게 된다. 이는 분노는 매우 위험하고, 위협적이며, 파괴적이고, 절대 수용 받을 수 없는 감정이기 때문에 억압 
하거나 다른 대상을 향해야 한다는 의식적/무의식적 믿음 때문이다. 결과적으로 개인은 분노를 자신에게 돌리게 된다. 이때 흔히 자기혐오의 감정을 느끼고, 그 결과 우울감과 자 존감의 저하가 일어난다.

자기애적 상처가 유발한 분노 반응으로 우울해지는 경우, 치료 과정에는 다음과 같은 일곱 가지 영역을 탐색해 가야 한다. 1) 분노를 인식하지 못하는 것에 대한 접근, 2) 특정한 분노 관련 환상 탐색, 3) 분노 경험 후 나타나는 특정한 죄책 감 반응 탐색, 4) 처벌에 대한 환상과 불안 탐색, 5) 경쟁적 감정과 공격성 사이의 연관 탐색, 6) 자기주장에 대해서 보 다 편안해질 수 있도록 돕는다, 7) 분노감이 자신을 향하고 있는 점에 대해서 인식하도록 돕는다. 이를 통해 예상되는 치료의 효과는 자신의 공격성에 대한 수용과 통제가 증가되 는 것이다. 그 결과 자기주장에 대해서 더욱 편안해지며, 분 노가 자기를 향하는 경향이 감소한다.

\section{가혹한 초자아의 영향, 죄책감과 수치감의 경험}

\section{(Severe superego, experience of guilt and shame)}

초자아는 자신의 충동과 행동을 제한하는 기능을 한다. 초 자아는 자기 자신의 생각, 욕구, 환상 등에 대해 이들이 적절 하고 수용할 만한 것인지 매우 위험하고 해로운 것인지를 판 단한다. 또한 자기 자신을 칭찬할 것인지 처벌할 것인지를 결 정하고 그 결과 개인은 자신에 대해서 만족감과 자랑스러움 을 경험하게 하기도 하고, 죄책감과 우울을 경험할 수도 있다.

강렬한 분노가 외부 대상에게 향하지 못하도록 하는 과정 에서 가혹한 초자아가 동원된다. 공격성이 자신을 향하도록 하는 것이다. 이러한 가혹한 초자아는 처벌적이고 비판적인 부모의 태도가 내면화되어 생겨나며 분노감, 탐욕, 시기, 성 욕 등과 관련된 다양한 소망들에 대한 지나친 자기 비난이 일어난다. 그 결과 자신에 대한 수치감, 죄책감, 부정적 자기 이미지를 경험하게 되고, 결국 자존감이 낮아지고 우울감이 발생한다.

가혹한 초자아 문제를 가진 환자의 치료 과정에서 다음과 같은 세 가지 영역에 대한 개입이 필요하다. 1) 숨겨진 죄책 감과 자기 처벌적 행동 패턴을 인식하도록 돕는다, 2) 죄책감 관련 환상을 탐색한다(guilt-laden fantasies), 3) 분노, 죄책 감, 자기 처벌로 이어지는 가학피학적 성격 특성을 인식하게 돕는다.

\section{대상과 자신에 대한 이상적 기대와 실망(Idealized and} devalued expectations of self, others)

내면 깊이 자리 잡은 자기애적 취약성을 가진 개인은 고통 스러운 자존감의 상처를 줄이고 자기애적 만족을 보강하기
위해서 스스로에 대해서 매우 높은 기대를 가지거나(high ego ideal) 중요한 대상을 이상화한다(idealization of others). 특 히, 공감적이지 못하며 현실적 한계를 부인하는 과대성을 가 진 부모 아래에서 성장한 경우, 개인은 부모의 비현실적인 기대와 비현실적으로 높은 자아 이상을 내면화하게 된다. 이 들은 흔히 완벽해 보이는 대상을 찾아 관계를 맺으려 하며, 그들의 완벽하고 강인한 능력이 마술적으로 자신에게 주어질 것이라는 희망을 갖는다. 이들은 이상화된 인물이나 단체와 자신을 동일시함으로써 자기 자신에게 특별한 '가치'가 다시 주어질 것이라고 믿는다. 반대로 타인을 비난하고 평가절하 함으로써 자신의 취약한 자존감을 방어하려는 시도를 하기도 하는데 이러한 무의식적 노력을 자기애적 방어라고 하겠다.

하지만 대상에 대한 이상적 기대가 무너지게 되면, 그 관 계는 더 이상 '특별함'을 제공하지 못하게 되고 자신과 타인 에 대해서 극심한 실망감과 분노가 일어나게 된다. 이때 자 신의 강렬한 분노로부터 사랑하는 대상을 보호하기 위해서 스스로를 비난하기도 하는데, 그 결과 자기혐오의 감정과 극 심한 무기력감을 경험하게 되며 우울감과 자존감의 저하가 발생된다.

이상화와 평가절하의 문제를 가진 우울 환자의 치료 과정 에서는 자신과 타인에 대한 이상화와 평가절하 패턴을 인식 하도록 도와야 한다. 이를 위해서 이상화와 평가절하가 가장 생생하게 드러나는 전이 관계를 탐색하며, 특히 이상적 대상 에 대한 '실망 이후' 발생하는 공격성이 어떻게 처리되고 행 동화되는지 이해하도록 도와야 한다.

\section{우울증과 관련된 다섯 가지 주요 방어기제}

앞서 언급한 것처럼 견딜 수 없는 고통스러운 감정들, 낮 은 자존감과 분노 등을 피하기 위해서 자아는 이상화와 평가 절하 외에도 다음과 같은 특정한 방어기제를 동원한다. 1) 감 정을 부인(denial, 나는 전혀 화가 나지 않았어!), 2) 투사 (projection, 분노하는 것은 내가 아닌 저 사람이다), 3) 수동 공격적 태도(passive aggression, 분노를 간접적으로 표현), 4) 반동 형성(reaction formation, 분노를 부인함과 동시에 지나치게 친절한 보상 행동과 감정 표현), 5) 공격자와의 동 일시(identification with aggressor, 분노를 자극한 대상을 강력하고 위협적인 존재로 느끼며, 흔히 그에게 죄책감을 느 낀다).

그 결과 대인관계적 맥락에서 갈등을 경험할 때, 나와 상 대방 모두 분노를 적절하게 다루지 못하고, 분노의 감정 아 래 있는 상처를 이해하지 못한다. 이렇게 되면 분노는 더욱 강렬해지고, 자기 자신을 향하게 되면 우울감은 증가된다. 반대로 분노가 외부를 향하게 되면 세상을 위협적이고 적대 
적인 곳, 나를 방치하고 파괴하려는 대상으로 인식하고 관계 에서 철수하며 사회적 고립은 커지게 된다.

의존성 우울(Anaclitic or dependent depression)과 자기 비판형 우울(Introjective or self-critical depression)

Blatt(2004)은 우울증을 크게 두 가지 유형으로 구분하였 다. 하나는 개인의 대인관계적 특성에서 발생하는 우울, 즉 의존성 우울(anaclitic or dependent depression)이고, 다른 하 나는 스스로에 대한 자기 정의(self-definition)와 관련된 우 울, 즉 자기 비난형 우울(introjective or self-critical depression)이다. 이 두 가지 우울의 역동을 살펴보면 아래와 같다.

\section{의존성 우울(Anaclitic or dependent depression)}

의존성 우울은 나를 만족시켜 줄 중요한 사람을 잃어버렸 을 때 오는 우울이다. 우울 증상과 함께 외로움, 절망감, 취 약감, 보호 받지 못하고, 돌봄 받지 못한 채 버림받을 것이라 는 강렬한 공포감을 경험하는 것이 특징이다. 이들은 어린 시절에 경험하지 못한 사랑과 돌봄, 보호에 대한 깊은 소망 이 내면에 있다.

의존성 우울은 양육자로부터 적절한 돌봄을 제공받지 못 한 결과, 자신의 욕구에 반응하고, 만족을 주는 대상을 내면 화하지 못한 채 성장할 때 발생한다. 스스로는 채울 수 없는 의존 욕구가 계속되면서 즉각적인 만족, 위로를 제공하는 대 상을 끊임없이 찾게 된다. 그러나 이런 의존대상에서 분리되 거나 대상을 잃게 되면 극심한 불안, 공포, 걱정을 경험한다. 이러한 괴로운 감정을 부인하기도 하지만, 의존대상을 잃게 되면 절박하게 새로운 대상을 찾게 된다. 이들의 경우 우울 증은 '대상 상실'에 의해 발생한다. 이들은 흔히 신체 증상을 호소하거나, 때로는 자살 시도나 과도한 약물복용을 통해 치 료자의 관심을 구한다(Blatt 1974).

특히 의존성 인격장애를 가진 우울 환자의 경우, 혼자서 어떤 기능도 적절히 수행할 수 없을 것이라는 환상과 믿음 이 존재한다. 이러한 믿음은 그들의 실제적 능력의 유무와 무관하게 의존대상과의 분리가 예상되는 상황에서 강렬한 불안을 유발한다. 또 이들은 흔히 관계를 유지하기 위해서 자기 자신에게 공격성을 돌린다. 왜냐하면 이들의 무의식에 는 자신의 공격성이 대상을 심각하게 손상시킬 것이라는 환 상이 존재하기 때문이다. 이러한 환상과 공포감은 공격성을 경험하고 표출하는 것에 대한 극도의 내적 갈등을 유발하고, 의존대상을 잃어버리지 않기 위해서 흔히 자기주장, 화, 부 동의(disagreement) 등의 직접적인 표현을 억제, 억압한다. 이를 위해 자기 비난, 부적절감, 수치감, 죄책감이 동원된다. 치료자는 우울 환자가 의존대상과의 관계에서 경험하는 죄
책감과 수치감을 직면하도록 돕고 그 아래 있는 다양한 환 상을 탐색할 필요가 있다. 이때 분노와 공격성의 처리 과정 을 함께 이해할 수 있고, 안전한 치료 관계 안에서 공격성을 숙달하고 보다 편안하게 자기 주장을 하는 능력을 발전시키 도록 도울 수 있다.

의존성이 강렬할수록 대상을 이상화하는 경향도 커진다. 대상을 이상화할 때, 강력한 힘을 가진 보호자가 함께 있기 때문에 개인은 위험으로부터 안전하게 보호 받을 수 있고, 자존감도 유지된다. 하지만 대상을 이상화할 때 자기 자신에 대한 현실적 지각은 어려워진다. 즉, 강력하고 완벽한 대상 에 비해 자신은 취약하고 부적절하고 불완전하게 지각된다. 그 결과 스스로에 대해서는 만성적인 부적절감과 자기애적 모멸감이 느껴진다.

앞서 이상화와 평가절하의 역동에서 살펴본 것처럼 이상 적 대상에 대한 실망이 일어나면, 공격성과 관련된 강렬한 무의식적 갈등이 발생하고, 이를 처리하는 과정에서 우울이 발생한다. 의존성 우울 환자의 치료 과정에서도 이러한 이상 화와 평가절하, 그리고 분노와 우울의 패턴을 인식하게 도울 필요가 있다. 더불어 안전하고 공고하며 오래 지속되는 치료 적 관계의 경험, 분리-개별화의 촉진, 자신과 대상을 보다 현 실적으로 평가하는 능력의 발전, 공격성에 대한 숙달과 자기 주장 능력의 촉진, 반복되는 실망과 부적절감과 같은 자기애 적 취약성의 감소 등이 의존성 우울 환자 치료의 초점이다.

\section{자기 비난형 우울(Introjective or self-critical depression)}

내 가치를 확인해 줄 삶의 목표가 성취되지 못할 때 오는 우울이다. 우울감과 함께 흔히 무가치감, 열등감, 실패감, 죄 책감을 경험하는 것이 특징이다. 이들은 자신의 문제에 대해 서 매우 가혹한 검열 과정을 갖고, 타인의 비난을 두려워하 며, 타인의 인정을 잃게 되는 것을 두려워한다. 인정받기 위 해서 이들은 꼻임없이 완벽을 추구하고 생산성에 몰두하는 한편, 경쟁적 성향이 강하기 때문에 타인을 공격하거나 비난 하는 경우가 많고, 타인에게도 요구적이다. 대개 커다란 성 취를 하지만, 그 만족감이 오래 가지 않는다(Blatt 2004). 매 우 유능하고 재능 있고, 야심만만하지만, 이들의 내면에는 자 기 가치, 자존감, 실패, 죄책감의 문제가 현저하여 비난과 실 패, 굴욕감을 경험할 때 우울증 발생과 자살 시도의 위험성 도 높다(Blatt 1974, 1982; Fazaa와 Page 2003).

\section{누가 통찰 지향적 역동정신치료에 적합한가?}

다음과 같은 심리적 특성을 가진 경우, 통찰 지향적 역동 정신치료에 적합하다. 1) 자신의 증상 아래 근원에 대해 이 해하고 싶은 동기가 있는 사람, 2) 심리적 심성을 가진 사람 
(ability to think psychologically), 3) 타인과 의미 있고 복잡 한 관계를 맺을 수 있고, 그 관계의 의미를 생각할 수 있는 사람, 4) 충동을 통제할 수 있는 사람, 5) 은유를 이해할 수 있 는 사람, 6) 자신의 정서적 상태를 인식할 수 있는 사람, 7) 현 실 판단력이 잘 유지되고 있는 사람.

반면 다음과 같은 심리적 특성이 있는 경우, 보다 지지적 인 정신치료가 적합하다. 1) 자신의 내적 동기(또는 타인의 동기)를 관찰하고 사유하는 데 어려움이 상당한 경우, 2) 좌 절을 견디는 것이 현저하게 어려운 사람, 3) 대인관계를 형성 하고 유지하는 것이 전반적으로 어려운 사람, 4) 치료자와의 치료적 동맹을 형성하는 것이 현저하게 어려운 사람, 5) 지능 이 낮은 사람, 6) 우울 증상이 지나치게 현저하여 심리치료를 효과적으로 할 수 없는 사람.

Levenson 등(2002)은 우울증에 대한 정신치료기법 중 대 인관계적 접근이 유용한 경우를 정리하였는데, 이는 치료자 가 구체적으로 문제 상황을 규정하고 해결 방법을 제안하는 형태이다. 우울증이 있으면서 아래 네 가지 상황이 원인이 된 환자들의 경우, 대인관계적 접근을 고려해 볼 수 있다. 1) a role transition 역할 전환 시기: 이혼, 은퇴, 이주, 질병, 2) interpersonal conflicts 배우자, 자녀, 동료 등과 대인관계 갈등을 겪고 있으며, 상대와 더 이상의 타협이 어렵다고 느끼는 경 우, 3) abnormal grief reactions 병적인 애도 반응을 겪는 경 우(정상적인 애도 과정을 진행하지 못하는 경우), 4) social isolation 사회적 기술의 결핍으로 고립된 경우

\section{우울에 대한 통찰 지향적 정신치료에서 단계별 과제}

$\operatorname{Busch}(2016)$ 는 우울의 정신역동적 정신치료의 치료 과정 을 초기, 중기, 종결기로 나누고, 각 단계별 과제를 아래와 같이 제안하였다.

\section{치료 초기 과제(Initial treatment phase)}

치료의 초기 과제는 평가와 치료 동맹의 확립에 있다. 이 를 위해서 치료자는 치료 틀을 확립하고(치료 횟수와 치료 비 계약), 탐색적 정신치료의 과정을 소개할 필요가 있다(자 유연상과 증상의 의미, 전이와 꿈 등에 대한 교육).

치료 동맹을 확립하기 위해서 치료자는 환자의 문제를 함 께 탐색해 가는 무비판적이고 공감적인 동반자(nonjudgmental, sympathetic partner) 역할을 할 수 있어야 하며, 동 시에 경험과 전문적인 지식을 가진 권위자(knowledgeable authority)의 역할을 할 수 있어야 한다. 특히 치료 초기에 환 자의 증상이 발생한 맥락과 의미를 규명하는 능력을 보여줄 때 치료 동맹 발전이 촉진된다.

또한 치료적 관계에 참여하는 것을 막는 장애물을 규명하
고 그것을 다루어 갈 필요가 있다. 특히 극심한 수치감과 노 출에 대한 공포감을 가지고 있는 경우, 치료 초기부터 자기 애적 문제를 해결해 가는 것이 매우 중요하다. 이를 위해서 수치감과 자기애적 취약성 문제가 환자에게 있다는 것을 조 기에 인식하고, 이것이 환자의 우울 증상에도 영향을 주고 있다는 것을 환자에게 이해하도록 돕는다. 이것은 초기 저항 을 극복하고 치료 동맹을 형성하는 데 도움이 된다.

한편, 치료의 도움을 받는 것에 대한 극도의 죄책감을 가 진 환자의 경우도 치료자와의 치료 관계 수립이 어렵게 된 다. 심한 죄책감을 가진 환자는 치료에 들어가는 것을 두려 워한다. 마치 치료자가 환자를 속여 자신이 스스로를 용서하 게 하지 않을까 두려워하게 된다. 이들의 무의식에는 자신이 더욱 강해지면 타인에게 심각한 손상을 초래할 것이라는 환 상이 존재 한다(Freud 1916; Klein 1940). 또는 치료 과정에 서 공격적 환상이나 성적 환상 등 자신에게 더 큰 죄책감을 느끼게 할 환상이 드러나는 것을 두려워한다. 이때 치료자는 환자의 죄책감의 강도가 특정한 상황에서 지나치게 과도해 진다는 것을 보도록 돕고, 이처럼 과도한 죄책감을 느끼는 기저의 이유에 대해서 의문을 갖도록 돕고 치료 과정에서 함 께 이해해 갈 것을 권하는 것이 좋다.

치료 초기 저항 중 또 다른 경우는 환자가 우울증에 대하 여 지나치게 단순한 관점을 가지고 있는 경우이다. 어떤 환 자들은 위험하고, 수치스럽고, 견디기 어려운 감정을 피하기 위해서 방어적으로 우울증에 대한 지나치게 단순한 설명을 한다. 예를 들어 우울 상태는 순전히 생물학적 원인이다라고 믿는다. 또는 최근에 일어난 상실 경험이 우울증의 원인이 며, 과거의 심리적 상처와는 관련 없다고 주장한다. 이때 치 료자는 환자의 관점을 존중하는 것이 좋다. 동시에 우울증을 일으키는 다양한 관점을 볼 수 있도록 환자의 시야를 넓히 는 노력을 해야 한다.

치료 초기의 또 다른 중요한 과제는 환자의 우울증 아래 있는 주요 정신역동을 구성하는 것이다. 환자의 우울 증상을 이해하기 위해 평가해야 할 주요 영역들은 아래와 같다. 환 자의 일반적 우울 증상, 개인만의 독특한 증상, 스트레스 요 인, 환경, 우울 증상 발병 직전의 감정 상태, 우울증을 촉발한 스트레스 사건, 그 당시에 경험한 감정과 환상은 무엇이었 나? 또한 어린 시절 가족 내에서 환자는 어떻게 자신의 감정 을 처리해 왔는가? 특히, 헤어짐이나 질병, 대상의 상실과 관 련하여 슬픔, 우울, 분노, 불안 등의 감정을 어떻게 처리해 왔 는가? 어린 시절에도 우울 증상이 있었는가? 환자에 대한 부 모의 양육 태도나 행동은 어떤 특징이 있었는가? 성인이 되 어서 인간관계의 특징, 갈등 상황, 주로 겪는 감정, 중요한 대 상이 환자에게 얼마나 반응적인지? 가족 내 우울증, 우울증 
환자에 대한 가족들의 태도 등의 발달력과 가족력을 수집한 다. 마지막으로 통찰 지향적(탐색적) 정신치료에 적합한지에 대한 평가가 필요하다.

\section{치료 중기의 과제(Middle phase of treatment)}

치료의 중기 과정은 우울에 대한 환자의 이해를 촉진하고, 우울증에 대한 취약성을 줄이고 재발을 방지하는 것을 목적 으로 한다. 이때 중심적인 역동을 명료화하고, 그것이 우울 증에 기여하는 과정을 구체적으로 그려 간다. 우울증에 대한 취약성을 줄여 가기 위해서는 우울증 아래 있는 역동에 대 한 이해가 필요하다. 동시에 치료동맹을 더 공고하게 하면서 전이를 다룰 수 있도록 한다. 우울 증상과 관련된 무의식적 과정에 대해서 더 넓고 깊은 이해를 할수록 개인은 우울 증 상을 더 통제할 수 있는 능력이 생겨난다. 특히 환자가 구체 적으로 그러한 역동을 과거에 경험했을 때, 현재 주위의 누 군가와 경험하고 있을 때, 치료자와의 전이 관계 안에서 경 험하고 있을 때 감정적으로 의미 있는 환상을 경험하게 되 며, 이를 재료로 분석해 갈 때 효과적이다. 또한 우울 환자 기저의 역동이 대인관계에 미치는 부정적인 영향을 인식하 도록 돕고, 그러한 병적인 대인관계 패턴이 변화하도록 돕는 다. 이때 주로 사용되는 치료 기법은 명료화, 직면, 해석, 역 전이에 주의를 기울여 이를 치료에 이용하는 것 등이 있다.

우울증 환자의 치료 중기 과정을 통해 예상되는 치료 효 과는 자존감 저하, 자존감 상실, 실망과 자기 비난 등 취약성 의 감소이다. 분노를 견디는 힘이 더욱 증가하고, 자신의 분 노 감정을 인식하는 능력이 증가하고, 분노를 자신에게로 돌 리는 경향이 감소하게 된다. 죄책감과 자기 처벌 행동이 감 소한다. 수치감과 이상화/평가절하가 줄어들게 되고, 그 결 과 대인관계가 향상된다.

\section{치료 종결기의 과제(Termination phase of treatment)}

종결의 결정은 매우 복잡하고, 개인마다 결정의 과정과 시 점도 차이가 있다. 일반적으로 아래와 같은 개선을 보인다면 종결을 고려해 볼 수 있다. 즉, 1) 우울증에 빠지는 취약성이 감소하여 상실, 실망, 비난에도 심각한 우울증에 빠지지 않 게 되었다, 2) 우울감과 공격성을 계속해서 조절해 나갈 수 있는 능력이 생겼다, 3) 이전에 비해서 죄책감과 자기 비난 (self-devaluation)의 경향성이 감소했다, 4) 자신과 타인의 행동, 그 행동 아래 있는 동기에 대해서 이전에 비해 훨씬 현 실적인 평가가 가능해졌다(내적 현실과 외적 현실의 구분).

종결기에는 치료자를 잃고, 치료가 종결되는 것과 관련된 다양한 감정들을 이해해 가는 것이 치료의 초점이 된다. 종결 은 중요한 전이 감정을 일으키기 때문에 우울증과 관련된 주
요 역동을 다룰 수 있는 특별한 기회를 제공한다. 동시에 치 료자와의 관계는 심리적으로 계속된다는 것을 인식함으로써 자기애적 상처에 대처할 수 있게 된다. 또한 치료 시간의 제 한, 치료의 종결에 따른 치료자를 향한 분노 감정을 다룬다.

이 과정을 통해 예상되는 종결기 치료의 효과는 다음과 같 다. 종결기에는 종결 시점이 다가올수록 일시적으로 우울 증 상이 악화될 수 있다. 환자는 이별과 상실의 감정을 강하게 재경험하면서 힘겨워할 수 있다. 하지만 환자는 이전에 비해 서 상실에 대한 대처 능력이 증가하고, 자존감의 상처에 대 한 대처 능력도 커진다. 분노를 더욱 건설적으로 이용할 수 있게 되고, 자신을 향한 분노가 감소한다. 더불어 죄책감과 자기 처벌의 욕구가 감소한다.

\section{요 약}

통찰 지향적 정신역동치료는 전이 관계 안에서 개인이 가 진 주요 정신역동 모델들을 이해해 가는 방향으로 치료가 전개된다. 따라서 각 환자의 중심적인 정신역동을 수립하는 것은 치료 과정을 설계하고 진행해 가는 데 매우 중요한 의미 를 가진다. 우울 환자에 대한 정신역동치료는 우울 증상의 경 감뿐만 아니라 주요 역동에 따른 전이와 저항을 이해하고 해 석해 감으로써 자아의 자기 관찰 능력을 촉진하여, 자기애적 취약성의 감소, 초자아 병리의 수정, 공격성의 숙달을 도와 성격구조의 변화를 도모한다. 본 논문에서는 Busch(2016)가 제시한 다섯 가지 주요 정신역동 모델과 Blatt(2004)이 제시 한 두 가지 정신역동 모델을 고찰하고, 각 역동에 따른 적절 한 치료 개입과 기법을 간략하게 소개하였다. 소개된 정신역 동 모델들은 환자와의 치료 동맹을 촉진시키고, 우울 환자의 정신역동치료의 단계별 과제를 세워 그에 맞는 기법을 체계 적으로 적용하는 데 유용하게 이용될 수 있다.

\section{Acknowledgments}

본 논문의 일부 내용은 2017년 10월 28일 한국정신분석학회 단 기역동 정신치료 전문과정에서 발표되었음.

\section{Conflicts of Interest}

The author has no financial conflicts of interest.

\section{REFERENCES}

Abraham K. Notes on the psycho-analytical investigation and treatment of manic-depressive insanity and allied conditions (1911). In: Abraham K. Selected papers on Psychoanalysis. 1st ed. London: Hogarth Press; 1927. p.137-156.

Abraham K. A short study of the development of the libido, viewed in the light of mental disorders (1924). In: Abraham K. Selected papers on psychoanalysis. 1st ed. London: Hogarth Press;1927. p.418-501.

Bibring E. The mechanism of depression. In: Greenacre P. Affective disorders. Psychoanalytic contributions to their study. Oxford: International 
Universities Press;1953. p.13-48.

Blatt SJ. Levels of object representation in anaclitic and introjective depression. Psychoanal Study Child 1974;29:107-157.

Blatt SJ, Quinlan DM, Chevron ES, McDonald C, Zuroff D. Dependency and self-criticism: psychological dimensions of depression. J Consult Clin Psychol 1982;50:113-124.

Blatt SJ. Experiences of depression: theoretical, clinical, and research perspectives. Washington, DC: American Psychological Association; 2004.

Bowlby J. Processes of mourning. Int J Psychoanal 1961;42:317-340.

Brenner C. Affects and psychic conflict. Psychoanal Q 1975;44:5-28.

Brenner C. Depressive affect, anxiety, and psychic conflict in the phallicoedipal phase. Psychoanal Q 1979;48:177-197.

Busch FN, Rudden M, Shapiro T. Psychodynamic treatment of depression. 2nd ed. Washington, DC: American Psychiatric Association Publishing;2016.

Davanloo H. Short-term dynamic psychotherapy. New York, NY: Jason Aronson Press; 1980.

De Jonghe F, Rijnierse P, Janssen R. Psychoanalytic supportive psychotherapy. J Am Psychoanal Assoc 1994;42:421-446.

Driessen E, Cuijpers P, de Maat SC, Abbass AA, de Jonghe F, Dekker JJ. The efficacy of short-term psychodynamic psychotherapy for depression: a meta-analysis. Clin Psychol Rev 2010;30:25-36.

Fazaa N, Page S. Dependency and self-criticism as predictors of suicidal behavior. Suicide Life Threat Behav 2003;33:172-185.

Fonagy P, Target M. Attachment and reflective function: their role in self-organization. Dev Psychopathol 1997;9:679-700.

Freud S. The ego and the id. SE 19. London: Hogarth Press;1923.

Freud S. Inhibitions, symptoms and anxiety. In: Strachey J, Freud A. The standard edition of the complete psychological works of Sigmund Freud. London: The Hogarth Press; 1926.

Freud S. Some character-types met with in psychoanalytic work (1916). In: Strachey J (translated and edited). The standard edition of the complete psychological works of Sigmund Freud, vol 14. London: Hogarth Press;1957. p.316-331.

Freud S. Mourning and melancholia (1917). In: Strachey J(translated and edited). The standard edition of the complete psychological works of Sigmund Freud, vol 14. London: Hogarth Press;1957. p.239-258.
Jacobson E. Transference problems in the psychoanalytic treatment of severely depressive patients. J Am Psychoanal Assoc 1954;2:595-606.

Jacobson E. Depression: comparative studies of normal, neurotic, and psychotic conditions. New York, NY: International Universities Press; 1971.

Jacobson E. The psychoanalytic treatment of depressive patients. In: Anthony J, Benedek T. Depression and human existence. Boston, MA: Little, Brown \& Co.;1975. p.431-443.

Kernberg O. Some observations on the process of mourning. Int J Psychoanal 2010;91:601-619.

Klein M. Mourning and its relation to manic-depressive states. Int J Psychoanal 1940;21:125-153.

Kohut H. The analysis of the self: a systematic approach to the psychoanalytic treatment of narcissistic personality disorders. New York, NY: International Universities Press; 1971.

Levenson H, Butler SF, Powers TA, Beitman BD. Concise guide to brief dynamic and interpersonal therapy. 2nd ed. Washington, DC: American Psychiatric Association Publishing;2002.

Luborsky L. Principles of psychoanalytic psychotherapy: a manual for supportive-expressive treatment. New York, NY: Basic Books; 1984.

Malan DH. A study of brief psychotherapy. London: Tavistock Publications; 1963.

Mann J. Time limited psychotherapy. Cambridge, MA: Harvard University Press; 1973.

Pollack J, Horner A. Brief adaptation-oriented psychotherapy. In: Winston A. Clinical and research issues in short-term dynamic psychotherapy (Clinical insights). Washington, DC: American Psychiatric Press;1985.

Rado S. The problem of melancholia. Int J Psychoanal 1928;9:420-438.

Sifneos PE. Short-term dynamic psychotherapy: evaluation and technique. New York, NY: Plenum Medical;1979.

Strupp HH, Binder JL. Psychotherapy in a new key: a guide to time-limited dynamic psychotherapy. New York, NY: Basic Books; 1984.

Stone L. Psychoanalytic observations on the pathology of depressive illness: selected spheres of ambiguity or disagreement. J Am Psychoanal Assoc 1986;34:329-362.

Sandler J, Joffe WG. Notes on childhood depression. Int J Psychoanal 1965;46:88-96. 